Volume 7 Nomor 1 Tahun 2020

doi: 10.32505/tarbawi.v7i1.2062

\title{
Efektivitas Perangkat Pembelajaran menggunakan Model Treffinger untuk Meningkatkan Kemampuan Berpikir Kreatif
}

\author{
Risa Handayani \\ Dosen Matematika STAIN Teungku Dirundeng Meulaboh \\ risaahandayani@gmail.com
}

\begin{abstract}
The availability of learning tools is one indicator the teacher has prepared a learning plan properly. However, existing learning tools have not triggered students' creative thinking abilities. This study aims to produce learning tools by using the Treffinger learning model to improve the mathematical creative thinking ability of junior high school students. This type of research is development research. The results of this study indicate that the learning device meets the effective criteria. Effectiveness can be seen in the results of positive responses of students namely $89.5 \%$ and the results of student learning tests on the indicator of fluency reached $97.7 \%$, flexibility reached $86.7 \%$, and authenticity reached $23.5 \%$, so the ability to think creatively is at the level 3 (creative).
\end{abstract}

Keywords: Ability To Think Creatively, Learning Tools, Treffinger Learning Model.

\begin{abstract}
Abstrak.
Ketersediaan perangkat pembelajaran merupakan salah satu indikator guru telah menyusun rencana pembelajaran dengan baik. Namun, perangkat pembelajaran yang ada belum memicu kemampuan berpikir kreatif siswa. Penelitian ini bertujuan untuk menghasilkan perangkat pembelajaran dengan menggunakan model pembelajaran Treffinger untuk meningkatkan kemampuan berpikir kreatif matematis siswa SMP. Jenis penelitian ini adalah penelitian pengembangan. Hasil penelitian ini menunjukkan bahwa perangkat pembelajaran memenuhi kriteria efektif. Keefektifan terlihat pada hasil respon positif peserta didik yaitu $89,5 \%$ dan hasil tes belajar peserta didik pada indikator kelancaran mencapai 97,7\%, keluwesan mencapai 86,7\%, dan keaslian mencapai $23,5 \%$, sehingga kemampuan berpikir kreatif berada pada tingkat 3 (kreatif).
\end{abstract}

Kata Kunci: Model pembelajaran Treffinger, Kemampuan berpikir kreatif, Perangkat Pembelajaran. 


\section{A. Pendahuluan}

Salah satu tujuan pembelajaran matematika adalah peserta didik dapat menyelesaikan masalah matematika dengan mengembangkan kemampuan berpikir kreatif matematis. Saputra (2018) peserta didik kreatif dalam berpikir untuk memecahkan masalah merupakan salah tujuan yang harus dicapai dari mata pelajaran matematika. Dwijanto (2007) mengemukakan bahwa dalam pembelajaran matematika perlu dikembangkan kemampuan berpikir kreatif matematis, yaitu kemampuan untuk menyelesaikan matematika secara kreatif. Selanjutnya Robinson (2011) juga menyatakan bahwa berpikir kreatif merupakan hal penting dalam bidang sosial, sehingga dengan kemampuan berpikir kreatif manusia dapat meningkatkan kualitas hidupnya. Berdasarkan beberapa pendapat ahli tersebut maka dapat disimpulkan bahwa peserta didik harus memiliki kemampuan berpikir kreatif matematis.

Kenyataan di lapangan menunjukkan kemampuan berpikir kreatif peserta didik masih tergolong rendah, hal ini dibuktikan dengan tes yang dilakukan oleh Putri (2019) kepada 60 peserta didik dan ditemukan bahwa mayoritas peserta didik belum mampu menyelesaikan masalah yang memerlukan kemampuan berpikir kreatif. Hal ini berarti dalam mengemukakan gagasan atau memikirkan cara menyelesaikan masalah yang beragam, dan memunculkan sesuatu ide atau pengetahuan yang baru merupakan hal yang tidak biasa bagi peserta didik. Hal ini sejalan dengan pendapat yang dikemukakan oleh Amtiningsih (2016) peserta didik kurang kreatif dalam menyelesaikan permasalahan terbukti mayoritas jawaban bersumber dari satu buku paket.

Model pembelajaran Treffinger merupakan model pembelajaran yang memfasilitasi proses belajar mengajar kreatif. Hal ini sejalan dengan pendapat Wirahayu (2017) yang menyatakan bahwa model pembelajaran Treffinger merupakan cara untuk belajar kreatif, melalui tingkatan yang dimulai dengan unsur-unsur dasar ke fungsi-fungsi kreatif yang lebih kompeks. 
Menurut Shoimin (2014) model Treffinger untuk mendorong belajar kreatif menggambarkan susunan tiga tahap yang mulai dengan unsur-unsur dasar dan menanjak ke fungsi-fungsi berpikir yang lebih majemuk, peserta didik terlibat dalam kegiatan membangun keterampilan pada dua tahap pertama untuk kemudian menangani masalah kehidupan nyata pada tahap ketiga.

Peningkatan kemampuan berpikir kreatif matematis dapat dimulai dari pengembangan perangkat pembelajaran. Hal ini sejalan dengan pendapat Titin (2016) Perangkat pembelajaran yang dibuat seperti Rencana Pelaksanaan Pembelajaran (RPP), Lembar Kerja Peserta didik (LKPD), dan soal evaluasi kualitasnya juga harus diperhatikan untuk mendukung keberhasilan dalam proses pembelajaran. Menurut Nazarudin (2007) perangkat pembelajaran adalah sesuatu atau beberapa persiapan yang disusun oleh guru baik secara individu maupun kelompok (KKG atau MGMP) agar pelaksanaan dan evaluasi pembelajaran dapat dilakukan secara sistematis dan memperoleh hasil yang diinginkan. Zuhdan (2011) juga mengemukakan bahwa perangkat pembelajaran merupakan alat atau perlengkapan untuk melaksanakan proses yang memungkinkan pendidik dan peserta didik melakukan kegiatan pembelajaran.

Kenyataan di lapangan menunjukkan bahwa ketersediaan perangkat pembelajaran yang memicu kemampuan berpikir kreatif matematis masih belum maksimal. Hal ini dibuktikan dengan analisis kebutuhan yang dilakukan peneliti di tiga SMP kota Banda Aceh. Berikut ini disajikan salah satu penggalan RPP guru di salah satu SMP di kota Banda Aceh pada saat analisis kebutuhan dilakukan. 


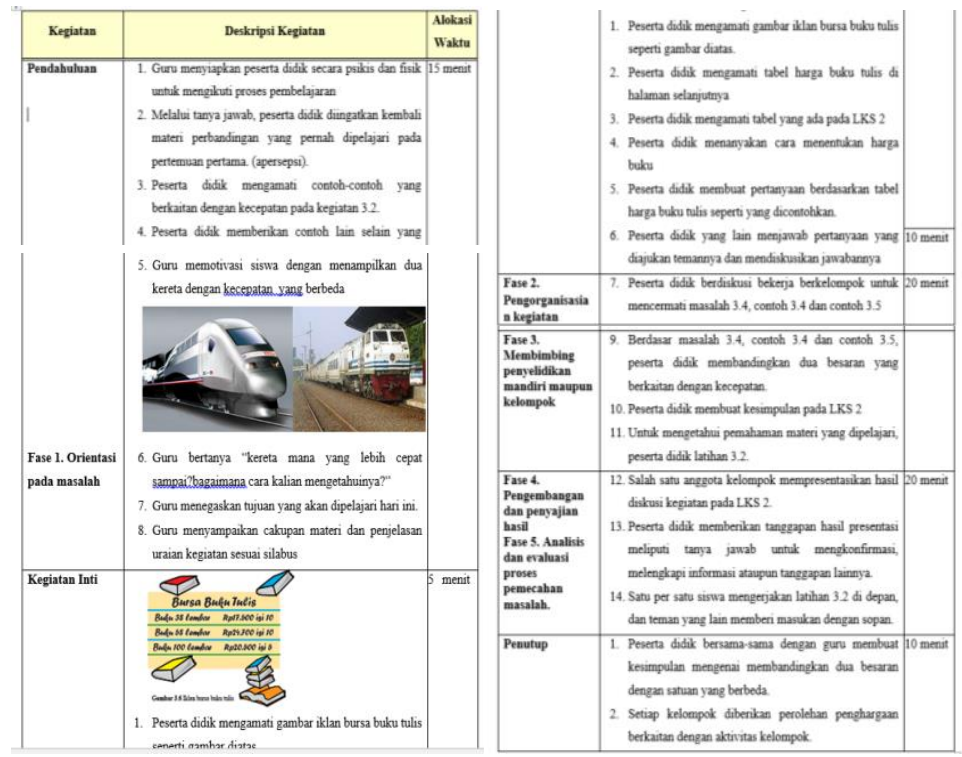

Gambar 1. Penggalan Salah Satu RPP Guru Saat Analisis Kebutuhan

Pada penggalan RPP di atas terlihat bahwa langkah pembelajaran yang direncanakan oleh guru belum terdapat langkah-langkah pembelajaran yang memicu peserta didik untuk berpikir kreatif. Hal ini dapat dilihat pada tahap lima pada RPP dituliskan "peserta didik memberikan tanggapan hasil presentasi meliputi tanya jawab untuk mengkonfirmasi, melengkapi informasi, ataupun tanggapan", seharusnya pada tahapan tersebut, guru hendaknya memberikan kesempatan untuk melihat kemungkinankemungkinan jawaban lainnya di kelompok lain sehingga peserta didik mengetahui ternyata terdapat penyelesaian/cara yang berbeda dari masalah yang diberikan. Padahal meskipun model pembelajaran yang digunakan adalah pembelajaran discovery learning, tahapan pembelajarannya juga dapat dituntun untuk mengajak peserta didik dalam menyelesaikan masalah dengan berbagai cara/penyelesaian.

Selain tidak tersedianya perangkat pembelajaran dengan menggunakan model pembelajaran Treffinger atau model pembelajaran yang memicu kemampuan berpikir kreartif matematis peserta didik, juga ditemukan bahwa perangkat pembelajaran yaitu RPP yang digunakan guru belum sesuai dengan tuntutan kurikulum. Nurjaya (2013) mengemukakan bahwa guru masih kebingungan membuat perangkat pembelajaran yang sesuai dengan 
harapan kurikulum. Akibatnya perangkat pembelajaran yang dihasilkan guru sangat jauh dari tuntutan kurikulum. Hal ini sesuai dengan RPP guru yang ditelaah oleh peneliti di salah satu SMP di kota Banda Aceh.

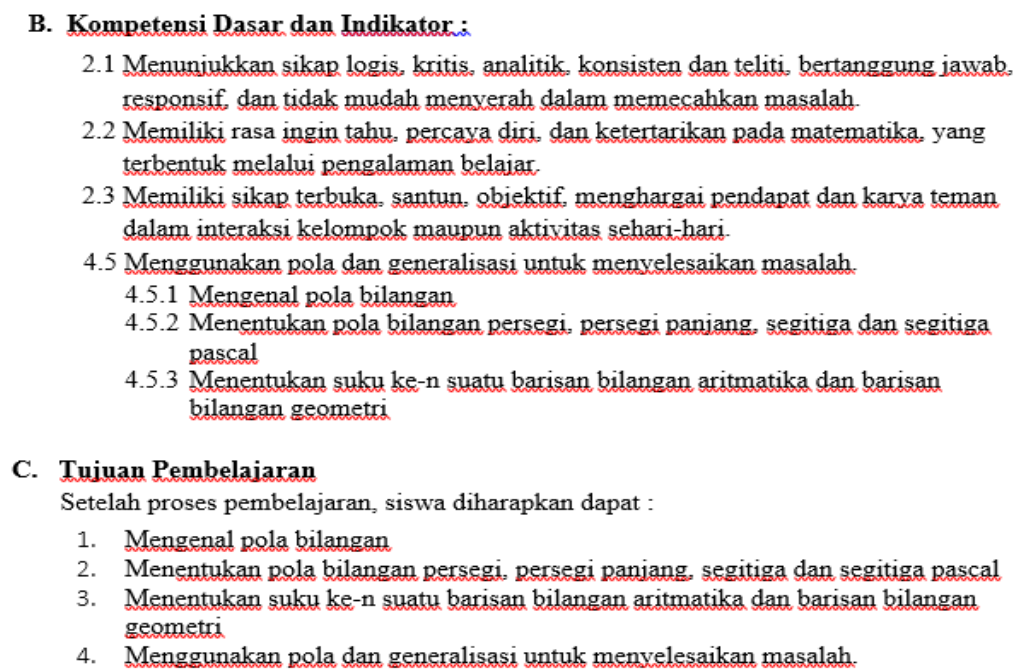

Gambar 2. Penggalan RPP Guru SMP

Pada penggalan RPP di atas dapat dilihat bahwa RPP tersebut tidak mencantumkan kompetensi dasar dan indikator nomor tiga yang merupakan salah satu komponen penting pada penyusunan RPP yaitu untuk mengukur pengetahuan peserta didik. Padahal pada tujuan pembelajaran tertulis bahwa "peserta didik diharapkan dapat mengenal pola bilangan, menentukan pola bilangan persegi, persegi panjang, segitiga, dan segitiga pascal, menentukan suku ke-n suatu barisan bilangan aritmetika dan barisan bilangan geometri" yang merupakan tujuan pembelajaran untuk mengukur pengetahuan peserta didik. Namun pada penggalan RPP di atas indikator yang mengukur pengetahuan peserta didik dituliskan pada indikator nomor empat yaitu untuk mengukur keterampilam peserta didik. Artinya pada penggalan RPP tersebut, selain mengukur keterampilan, guru juga merencanakan proses pembelajaran yang mengukur pengetahuan peserta didik. Hal ini juga sesuai dengan hasil wawancara yang dilakukan peneliti terhadap guru yang menggunakan RPP tersebut yaitu guru merencanakan mengukur pengetahuan peserta didik karena penggalan RPP tersebut merupakan 
penggalan RPP pada pertemuan pertama sehingga tidak mungkin pengetahuan peserta didik tidak diukur.

Selain itu, tujuan pembelajaran yang ingin dicapai belum menggunakan kata kerja operasional yang dapat diamati dan diukur, padahal berdasarkan hasil wawancara yang telah dilakukan peneliti, sekolah tersebut telah menerapkan kurikulum 2013 edisi revisi 2016. Hal ini berarti terdapat perbedaan antara RPP yang digunakan guru dengan tuntutan kurikulum yang diterapkan di sekolah tersebut. Kemudian disajikan pula penggalan tahap pembelajaran yang terdapat pada RPP tersebut pada gambar 1.2 sebagaimana berikut.

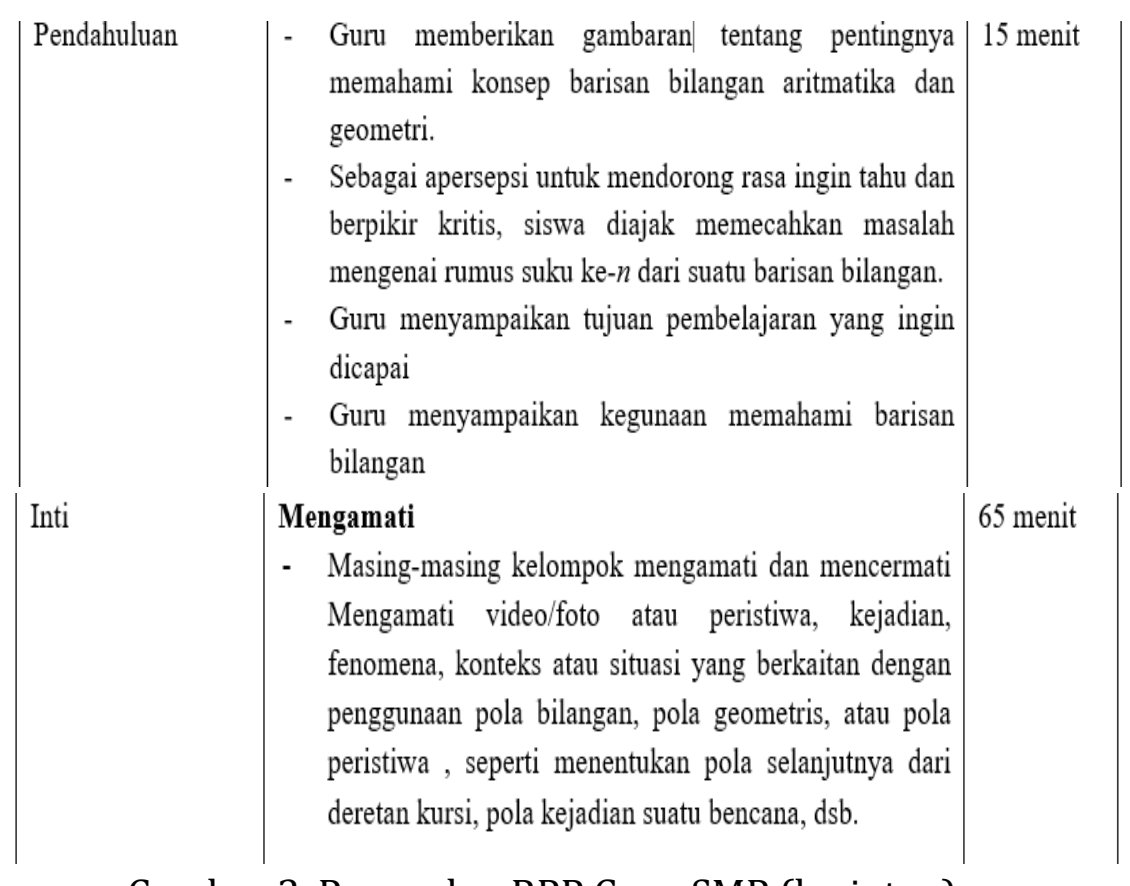

Gambar 3. Penggalan RPP Guru SMP (lanjutan)

Pada penggalan RPP di atas terlihat bahwa tahapan pembelajaran yang terdapat pada RPP tersebut dituliskan tidak detail, misalnya pada tahap pendahuluan dituliskan bahwa "guru menyampaikan kegunaan memahami barisan bilangan", seharusnya pada tahap tersebut dituliskan pula cara/strategi guru dalam menyampaikan manfaat belajar pola bilangan. Berdasarkan uraian-uraian di atas, maka dapat dikatakan bahwa RPP yang digunakan oleh guru masih belum sesuai dengan yang diharapkan. 
Berdasarkan uraian-uraian di atas, maka perlu adanya pengembangan perangkat pembelajaran matematika yang bertujuan untuk meningkatkan kemampuan berpikir kreatif peserta didik di SMP. Oleh karena itu peneliti tertarik untuk melakukan penelitian dengan judul "Keefektifan Perangkat Pembelajaran Matematika Menggunakan Model Pembelajaran Treffinger untuk Meningkatkan Kemampuan Berpikir Kreatif Matematis". Tujuan dari penelitian ini adalah untuk menghasilkan perangkat pembelajaran matematika dengan menggunakan model pembelajaran Treffinger untuk meningkatkan kemampuan berpikir kreatif matematis yang efektif.

\section{B. Metode}

Jenis penelitian ini adalah penelitian pengembangan. Sedangkan subjek ujicoba dalam penelitian ini adalah peserta didik kelas VII yang terdiri dari 30 peserta didik di MTsN 3 Meulaboh. Pemilihan sekolah berdasarkan pertimbangan bahwa sekolah tersebut sudah menjalankan revisi kurikulum Permendikbud No. 24 tahun 2016.

Pemilihan subjek ujicoba berdasarkan analisis kebutuhan yang dilakukan peneliti di tahap awal bahwa belum tersedia perangkat pembelajaran matematika dengan menggunakan model pembelajaran Treffinger atau model pembelajaran yang memicu kemampuan berpikir kreatif matematis sehingga dibutuhkan perangkat pembelajaran matematika dengan model pembelajaran Treffinger untuk meningkatkan kemampuan berpikir kreatif matematis peserta didik. Perangkat pembelajaran yang akan dikembangkan pada penelitian ini adalah Rencana Pelaksanaan Pembelajaran (RPP), Lembar Kerja Peserta Didik (LKPD), Tes Hasil Belajar (THB) dan materi ajar. Adapun langkah-langkah yang akan dilakukan dalam pengembangan perangkat pembelajaran ini mengikuti tahapan model pengembangan ADDIE menurut Branch (2009). 
Analisis uji efektivitas perangkat pembelajaran dilakukan dengan dua cara, yaitu:

1) Angket respon peserta didik

Data angket respon peserta didik terhadap perangkat pembelajaran yang dikembangkan dianalisis secara deskriptif dengan persentase. Persentase dari setiap respon peserta didik dihitung dengan rumus:

$\frac{\text { Jumlah respon positif siswa tiap aspek yang muncul }}{\text { jumlah seluruh peserta didik }} \times 100 \%$

Untuk menentukan keefektifan perangkat pembelajaran berdasarkan respon peserta didik adalah apabila peserta didik yang memberikan respon positif minimal $80 \%$ dari jumlah peserta didik sebagai objek penelitian (Hobri, 2010). Respon secara kualitatif yaitu saran-saran atau tanggapan dari peserta didik secara deskriptif/naratif juga menjadi salah satu pertimbangan untuk perbaikan perangkat pembelajaran yang dikembangkan. Angket respon peserta didik pada penelitian ini diadaptasi dari angket respon peserta didik yang digunakan oleh Ikhsan (2012).

2) Tes Hasil Belajar

Tes hasil belajar yang dimaksudkan pada penelitian ini adalah tes kemampuan berpikir kreatif dengan indikatornya kelancaran, keluwesan, dan keaslian. Tes hasil belajar yang digunakan merupakan tes hasil belajar yang dikembangkan oleh peneliti sendiri dan sudah divalidasi oleh para ahli, serta diujicobakan kepada peserta didik kelas VII. Data tentang hasil belajar peserta didik dinilai berdasarkan rubrik untuk mengukur kemampuan berpikir kreatif dan dianalisis secara deskriptif dengan cara mengukur kriteria tingkat berpikir kreatif matematis menurut Siswono (2007). Adapun tingkat penjenjangan yang tersebut dapat dilihat pada tabel di bawah ini. 
Tabel 2. Penjenjangan Kemampuan Berpikir Kreatif

\begin{tabular}{|lll|l|}
\hline \multicolumn{2}{|c|}{ Tingkat } & \multicolumn{1}{|c|}{ Karakteristik } \\
\hline $\begin{array}{l}\text { Tingkat } 4 \\
\text { Kreatif) }\end{array}$ & (Sangat & $\begin{array}{l}\text { Peserta didik mampu menunjukkan } \\
\text { kelancaran, keluwesan, dan keaslian atau } \\
\text { keaslian dan keluwesan dalam memecahkan } \\
\text { maupun mengajukan masalah }\end{array}$ \\
\hline Tingkat 3 (Kreatif) & $\begin{array}{l}\text { Peserta didik mampu menunjukkan kelancaran } \\
\text { dan keaslian atau kelancaran dan keluwesan } \\
\text { dalam memecahkan masalah maupun } \\
\text { mengajukan masalah }\end{array}$ \\
\hline $\begin{array}{l}\text { Tingkat } 2 \\
\text { Kreatif) }\end{array}$ & (Cukup & $\begin{array}{l}\text { Peserta didik mampu menunjukkan kebaruan } \\
\text { atau keluwesan dalam memecahkan masalah } \\
\text { maupun mengajukan masalah }\end{array}$ \\
\hline $\begin{array}{l}\text { Tingkat } 1 \\
\text { Kreatif) }\end{array}$ & (Kurang & $\begin{array}{l}\text { Peserta didik mampu menunjukkan kelancaran } \\
\text { dalam memecahkan masalah maupun } \\
\text { mengajukan masalah }\end{array}$ \\
\hline $\begin{array}{l}\text { Tingkat } \\
\text { Kreatif) }\end{array}$ & 0 & (Tidak & $\begin{array}{l}\text { Peserta didik tidak mampu menunjukkan } \\
\text { ketiga aspek indikator berpikir kreatif }\end{array}$ \\
\hline
\end{tabular}

Oleh karena itu, untuk menentukan kriteria keefektifan berdasarkan tes hasil belajar apabila minimal 80\% peserta didik memperoleh tingkat 3 pada penjenjangan yang telah ditentukan tersebut. Perangkat pembelajaran dikatakan efektif jika memenuhi semua kriteria uji efektivitas yang telah ditentukan di atas.

\section{Hasil dan Pembahasan}

Indikator yang digunakan untuk menyatakan bahwa perangkat pembelajaran yang dikembangkan efektif berdasarkan angket respon peserta didik apabila mencapai $80 \%$ respon positif dan hasil tes belajar peserta didik mencapai minimal tingkat tiga (kreatif) sesuai dengan jenjang kemampuan berpikir kreatif yang telah ditentukan. Sesuai dengan Nieveen (1999) yang mengaitkan efektivitas perangkat dengan dua aspek, yaitu (a) ahli dan praktisi berdasarkan pengalamannya mengatakan bahwa perangkat tersebut efektif, dan (b) dalam operasionalnya perangkat tersebut memberikan hasil yang sesuai dengan target yang direncanakan. Berdasarkan hasil ujicoba lapangan diperoleh data untuk mengukur efektivitas perangkat pembelajaran dengan menggunakan model pembelajaran Treffinger untuk 
meningkatkan kemampuan berpikir kreatif matematis. Data tersebut diperoleh dari hasil analisis angket respon peserta didik dan penilaian tes hasil belajar peserta didik. Adapun hasil analisis selengkapnya diuraikan sebagai berikut.

\section{a) Data Hasil Analisis Angket Respon Peserta Didik}

Hasil analisis respon peserta didik menunjukkan bahwa seluruh peserta didik kelas VII merasa senang terhadap LKPD, THB dan cara guru mengajar. Sedangkan sebesar 98\% peserta didik merasa senang terhadap suasana pembelajaran menggunakan model pembelajaran Treffinger. Kemudian seluruh peserta didik juga menyatakan bahwa LKPD yang diberikan merupakan hal yang baru mereka dapatkan selama proses belajar matematika di kelas.

Sedangkan $60 \%$ peserta didik merespon bahwa suasana pembelajaran dan THB merupakan hal yang baru, dan 90\% peserta didik merespon cara guru mengajar merupakan hal yang baru. Selanjutnya sebanyak 93\% peserta didik berminat dalam mengikuti pembelajaran selanjutnya menggunakan langkah-langkah/kegiatan-kegiatan yang terdapat pada LKPD dengan menggunakan model pembelajaran Treffinger. Lalu 83\% peserta didik merespon bahwa bahasa yang digunakan dalam LKPD jelas.

Sedangkan $86 \%$ peserta didik merespon bahasa yang digunakan dalam THB jelas. Hal ini berarti bahasa yang digunakan pada LKPD maupun THB mudah dipahami dan tidak mengandung penafsiran ganda. Dengan demikian, rata-rata persentase peserta didik memperoleh respon positif yaitu $89,5 \%$. Menurut kriteria yang telah ditetapkan maka respon peserta didik termasuk dalam kategori positif. Selain itu, peserta didik juga memberikan komentar positif terhadap pembelajaran matematika menggunakan model pembelajaran Treffinger. Adapun komentar peserta didik terhadap proses belajar mengajar menggunakan perangkat pembelajaran Treffinger yang terdapat pada angket respon peserta didik dapat dilihat pada gambar di bawah ini. 
Komentar:

Pembelajaran ini berjalan dan berlangsung dengan seru dan baru pertama katimua ada

di serraah saya. Hal wang seru dalam proses belajar adalah pada soat mencari

lebih clari 1 cara dalam menentukan kas suatu bangun datar . Tidak hanja itu dalam

proses belajar - mengajar juga tidak terlaiu tegang dan tidak terialu santai pula
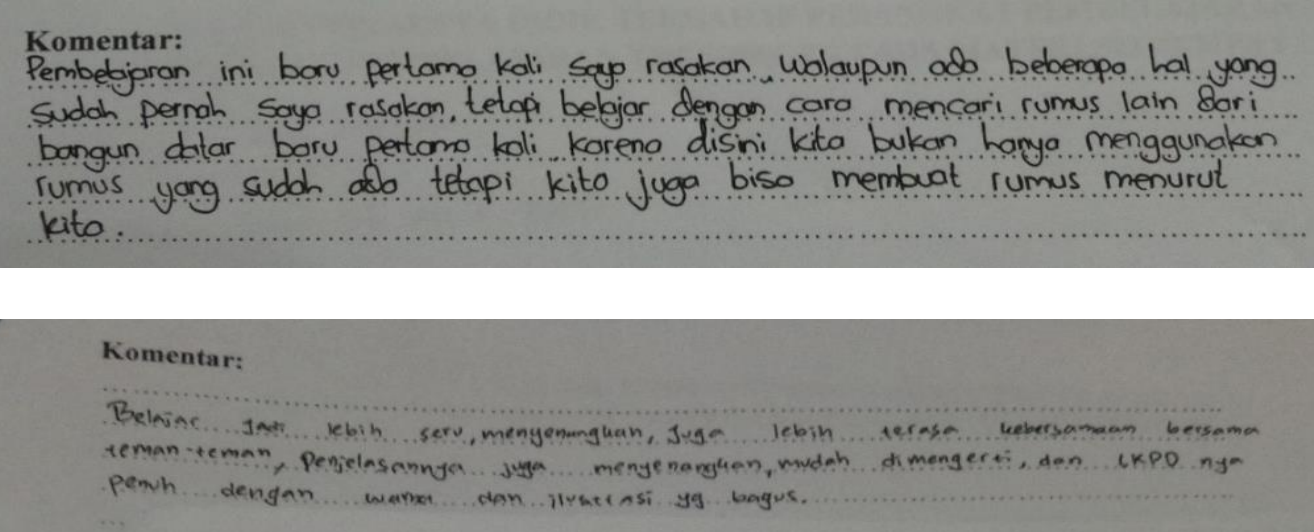

Gambar 4. Komentar Peserta Didik

Komentar peseta didik terhadap proses belajar mengajar menggunakan perangkat pembelajaran yang dikembangkan direspon sangat positif. Peserta didik merasa senang dan tertarik mengikuti pembelajaran yang menuntut mereka dalam menyelesaikan masalah matematika dengan banyak cara/penyelesaian. Hal ini disebabkan pembelajaran kreatif merupakan hal yang baru saja dirasakan.

Namun, berdasarkan persentase rata-rata juga diperoleh 10,5\% respon negatif. Dalam hal ini peneliti melakukan wawancara kepada salah satu peserta didik yang merespon negatif dan diperoleh bahwa peserta didik tersebut merasa senang terhadap pembelajaran dengan menggunakan model pembelajaran Treffinger karena menuntut banyak cara/penyelesaian dalam memecahkan masalah matematika, namun LKPD dan THB bukan merupakan hal yang baru ia peroleh karena biasanya dalam pembelajaran matematika di sekolah guru juga memberikan LKPD dan THB walaupun LKPD dan THB yang diberikan guru disajikan hanya berupa soal-soal saja tidak menggunakan gambar-gambar atau warnawarna yang menarik perhatian peserta didik. Selanjutnya peneliti juga melakukan wawancara kepada guru yang mengajar matematika di kelas 
tersebut dan diperoleh bahwa peserta didik yang memberikan respon negatif merupakan peserta didik yang tidak menyukai pelajaran matematika dan selalu memperoleh nilai rendah di kelasnya.

\section{b) Data Hasil Analisis Tes Hasil Belajar Peserta Didik}

Data untuk tes hasil belajar peserta didik diperoleh dari tes yang dilakukan setelah pembelajaran dilaksanakan. Adapun soal-soal yang diberikan berupa soal-soal pada lembar Tes Hasil Belajar (THB) yang dikembangkan. Secara umum hasil tes kemampuan berpikir kreatif matematis peserta didik pada indikator kelancaran (fluency) mencapai 97,7\%, indikator keluwesan (flexibility) mencapai 86,7\%, dan indikator keaslian (originality) mencapai 23,5\%. Berdasarkan analisis tersebut, maka secara umum lebih dari $80 \%$ peserta didik memenuhi indikator kelancaran (fluency), dan keluwesan (flexibility). Hal ini disebabkan karena pada perangkat pembelajaran yaitu pada LKPD maupun THB menuliskan perintah soal yang menuntut peserta didik untuk menyelesaikan masalah dengan berbagai cara/penyelesaian. Sedangkan kurang dari 30\% peserta didik memenuhi indikator keaslian (originality). Hal ini disebabkan soal nomor satu yang terdapat pada THB tidak mendukung untuk mengukur indikator keaslian (originality) peserta didik. Oleh karena itu, hasil belajar yang diperoleh adalah peserta didik dapat menyelesaikan masalah dengan memenuhi indikator kelancaran (fluency), dan keluwesan (flexibility) sehingga pada penjenjangan kemampuan berpikir kreatif matematis yang ditentukan mencapai tingkat 3 (kreatif).

Berdasarkan hal tersebut maka dapat disimpulkan bahwa perangkat pembelajaran yang dikembangkan memenuhi kriteria efektif. Hal ini disebabkan oleh perangkat pembelajaran dikembangkan mengikuti langkah-langkah model pembelajaran Treffinger yang memberikan kesempatan kepada peserta didik dalam kemampuan berpikir kreatif matematis yaitu pada tahap basic tools atau tahap pertama pada model pembelajaran Treffinger peserta didik diberikan soal-soal terbuka atau 
divergen, sehingga peserta didik diberikan kesempatan untuk mempelajari sejumlah teknik/ketrampilan yang beragam dalam menyelesaikan masalah dengan membuka sudut pandang peserta didik, menghidupkan imajinasi, dan membangkitkan ide-ide peserta didik pada proses pembelajaran.

Hal ini sejalan dengan pendapat Johnson (2011) yang mengemukakan bahwa berpikir kreatif merupakan sebuah kebiasaan dari pikiran yang dilatih dengan memperhatikan intuisi, menghidupkan imajinasi, mengungkapkan kemungkinan-kemungkinan baru, membuka sudut pandang yang menakjubkan, dan membangkitkan ide-ide yang tidak terduga. Munandar (2012) juga mengungkapkan bahwa tahap I pada model pembelajaran Treffinger merupakan landasan atau dasar dimana belajar kreatif berkembang. Selanjutnya pada tahap II yaitu practice with process, peserta didik diberi kesempatan untuk menerapkan keterampilan yang telah dipelajari pada tahap I dalam situasi praktis.

Hal ini sesuai dengan pendapat Munandar (2012) Pada tahap II merupakan satu tahap dalam proses gerak ke arah belajar kreatif, dan bukan merupakan tujuan akhir tersendiri. Kemudian pada tahap III diberikan masalah yang berkaitan dengan masalah dalam kehidupan sehari-hari yang juga menuntut peserta didik untuk menyelesaikan masalah tersebut dalam banyak cara/penyelesaian. Menurut Pehkonen (1997), kreativitas tidak hanya ditemukan dalam bidang tertentu, misalnya seni dan sains, melainkan juga merupakan bagian kehidupan sehari-hari.

Hal lain yang menyebabkan perangkat pembelajaran yang dikembangkan dinyatakan efektif adalah soal-soal yang diberikan pada LKPD maupun THB, perintah soal dituliskan secara detail dengan menuliskan bahwa peserta didik hendaknya dapat menyelesaikan masalah dengan langkah-langkah penyelesaian yang detail dan minimal mejawab dengan dua cara/penyelesaian. Dengan kata lain soal-soal yang diberikan pada THB maupun LKPD merupakan soal-soal terbuka atau divergen yang memberikan kesempatan kepada peserta didik untuk 
menyelesaikan banyak cara/penyelesaian. Hal ini sejalan dengan Mahmudi (2010) yang mengemukakan bahwa penggunaan soal terbuka dapat memicu tumbuhnya kemampuan berpikir kreatif.

\section{Kesimpulan}

Hasil pengembangan perangkat pembelajaran yang efektif terlihat dari respon peserta didik dan tes hasil belajar yang dilakukan. Hasil respon peserta didik terhadap perangkat pembelajaran diperoleh persentase 89,5\% peserta didik merespon positif. Sedangkan THB menunjukkan bahwa kemampuan berpikir kreatif matematis peserta didik berada pada tingkat 3 (kreatif).

\section{DAFTAR PUSTAKA}

Amtiningsih, S., Dwiastuti, S., \& Sari, D. P. (2016). Peningkatan Kemampuan Berpikir Kreatif melalui Penerapan Guided Inquiry dipadu Brainstorming pada Materi Pencemaran Air. In Proceeding Biology Education Conference: Biology, Science, Enviromental, and Learning (Vol. 13, No. 1, pp. 868-872).

Branch, R.M.(2009).Instructional Design : The ADDIE Approach. New York: Springer Science \& Business Media, LLC.

Dwijanto. (2007).Pengaruh pembelajaran berbasis masalah berbantuan komputer terhadap pencapaian kemampuan pemecahan masalah dan berpikir kreatif matematik mahapeserta didik. (Disertasi). Universitas Pendidikan Indonesia. Bandung.

Hobri. 2010. Metodologi Penelitian Pengembangan [Aplikasi Pada penelitian Pendidikan Matematika]. Jember : Pena Salsabila

Ihksan, M. (2012). Pengembangan Model Pembelajaran Berbasis Teori Van Hiele Untuk Meningkatkan Kemampuan Geometri Peserta didik SMP Di Kota Banda Aceh. Jurnal Pengajaran MIPA, 17(2), 164-172.

Johnson, S. (2011). Where good ideas come from: the seven patterns of innovation. Penguin UK.

Mahmudi, A. (2010). Mengukur Kemampuan Berpikir Kreatif Matematis. Makalah Disajikan Pada Konferensi Nasional Matematika XV UNIMA Manado, 30 Juni-3 Juli 2010. Tidak diterbitkan. Universitas Negeri Yogyakarta. 
Munandar, U. (2012). Pengembangan Kreativitas Anak Berbakat. Jakarta: Rineka Cipta.

Nazarudin. 2007. Manajemen Pembelajaran : Implementasi, Konsep, Karakteristik, Metodologi Pendidikan Agama Islam di Sekolah Umum. Yogyakarta : Teras

Nieveen, N. (1999). Prototyping to Reach Product Quality. Dalam Plomp, T; Nieveen, N; Gustafson, K; Branch, R.M; dan van den Akker, J (eds). Design Approaches and Tools in Education and Training. London: Kluwer Academic Publisher

Nurjaya. (2013). Pelatihan Penyusunan Perangkat Pembelajaran Bermuatan Pendidikan Karakter sesuai Amanat Kurikulum 2013 pada Guru-guru Sekolah Dasar Nomor 1. Kapal. Universitas Ganesha Singaraja: Bali.

Pehkonen, E. (1997). The state-of-art in mathematical creativity. ZDM, 29(3), 63-67.

Putri, C. A., Munzir, S., \& Abidin, Z. (2019). Kemampuan Berpikir Kreatif Matematis Peserta didik melalui Model Pembelajaran Brain-Based Learning. Jurnal Didaktik Matematika, 6(1), 12-27.

Robinson, J. R. (2011). Webster's dictionary definition of creativity. Online Journal for Workforce Education and Development, 3(2), 34-47.

Saputra, H. (2018, July 30). Kemampuan Berpikir Kreatif Matematis. https://doi.org/10.17605/OSF.IO/5ZNUK

Siswono, T. Y. E. (2007). Penjenjangan Kemampuan Berpikir Kreatif dan Identifikasi Tahap Berpikir Kreatif Peserta didik dalam Memecahkan dan Mengajukan Masalah Matematika. Disertasi. Tidak diterbitkan. Universitas Negeri Surabaya.

Shoimin, A. (2014). 68 Model Pembelajaran Inovatif dalam Kurikulum 2013. Yogyakarta: Ar-Ruzz Media.

Titin, T. (2016). Penyusunan perangkat pembelajaran pada materi ruang lingkup biologi kelas X SMA. Jurnal Pendidikan Matematika dan IPA, $7(1), 45-56$.

Wirahayu, Y. A., Purwito, H., \& Juarti, J. (2018). Penerapan Model Pembelajaran Treffinger dan Ketrampilan Berpikir Divergen Mahapeserta didik. Jurnal Pendidikan Geografi: Kajian, Teori, dan Praktek dalam Bidang Pendidikan dan Ilmu Geografi, 23(1), 30-40. 
Zuhdan, K., \& Tim. (2011). Pengembangan Perangkat Pembelajaran Sains Terpadu untuk Meningkatkan Kognitif, Keterampilan Proses, Kreativitas serta Menerapkan Konsep Ilmiah Peserta Didik SMP. Yogyakarta: UNY. 